\title{
STRATEGI KEKUATAN LOGISTIK UNTUK MENINGKATKAN KINERJA DI SEKTOR INDUSTRI PAKAIAN JADI
}

\author{
Rindang Matoati ${ }^{1}$ \\ Rr. Siti Muslikhah ${ }^{2}$ \\ Nisa Zahra ${ }^{1}$ \\ Eka Noviani Azis ${ }^{1}$ \\ Akasyah Palahuddin ${ }^{1}$ \\ Institut Pertanian Bogor ${ }^{1}$ \\ Universitas Islam Indonesia ${ }^{2}$ \\ r.matoati@gmail.com
}

\begin{abstract}
In modern era, there is a change in human basic needs for apparel that will make business in fashion industry become interesting dan increasing siginificantly. The growth of apparel industry contributes wealth enhancement of the stakeholders, starting from suppliers, small producers to big producers -such as small medium entreprises to national companies, and distributors. But there are also some obstacles faced by those stakeholders that slower their improving performance in Indonesia's apparel industry development such as logistics problem, especially in Jabodetabek (Jakarta, Bogor, Depok, Tangerang, Bekasi) area. The purposes of this research are: 1) To identify the strengths, weaknesses, opportunity and threat of logistics in apparel industry, 2)To formulate strategy to advantage the power of logistics as an effort to improve apparel industry performance in Jabodetabek area. This research took place in Jabodetabek, Indonesia. SWOT analysis and AHP method were used to analyze the data. The results of this research is aimed to provide a right management strategy of logistics to improve apparel industry performance in Jabodetabek.
\end{abstract}

Keywords: AHP, SWOT analysis, fashion, apparel, logistics

\section{PENDAHULUAN}

Hassler (2003) mengungkapkan bahwa perkembangan industri fashion di negara berkembang saat ini tengah mengalami pertumbuhan yang cukup signifikan seiring dengan mudahnya mengadaptasi teknologi dari industri ini. Hasil survei kementrian perindustrian (2014) menunjukkan pertumbuhan industri fashion terutama pakaian jadi di Indonesia mengalami rata-rata peningkatan 3,4\% per tahunnya. Dengan pertumbuhan tersebut, maka industri pakaian jadi memiliki potensi yag besar dalam meningkatkan pertumbuhan ekonomi Indonesia.

Untuk mewujudkan hal tersebut, industri pakaian jadi Indonesia masih menghadapi kendala besar terkait dengan logistik. Permasalahan logistik sebenarnya menjadi permasalan yang perlu perhatian khusus dari berbagai sektor industri. Indonesia sebagai salah satu negara anggota ASEAN, kini tengah 
mengahadapi persaingan yang sangat ketat dari berbagai negara anggota lainnya karena telah berlakunya pasar bebas di kawasan ASEAN (AEC). Logistik merupakan salah satu kunci untuk mencapai keberhasilan dalam persaingan di dunia industri. Namun kendalanya saat ini adalah kondisi logistik yang kurang bagi perkembangan industri dalam negeri. Sebagai contoh penerapan kebijakan pemerintah berupa pengetatan pengawasan barang impor sehingga banyak kontainer yang tertahan dan tidak dapat masuk ke Indonesia (Salim dan Ernawati, 2015). Hal tersebut membuat industri pakaian jadi di Indonesia terancam kekurangan bahan baku karena bahan baku yang sebagian besar adalah barang impor. Di samping kebijakan pemerintah, kondisi dari infrastruktur yang masih kurang baik dan pembangunannya yang belum merata menjadi hambatan dalam proses pendistribusian barang barang-barang pakaian yang sudah jadi maupun setengah jadi ke seluruh Indonesia, terlebih lagi kondisi wilayah Indonesia yang begitu luas dan terdiri dari kepulauan-kepulauan.

Untuk mengatasi segala permasalahan logistik tersebut, maka diperlukan langkahlangkah serta strategi yang tepat demi bertahan dan menangani ketatnya persaingan, khususnya di industri pakaian jadi yang kini sedang menagalami pertumbuhan yang cukup signifikan. Perumusan strategi-strategi tersebut diperoleh melalui pendapat berbagai pakar yang berkompeten dibidang pakaian jadi maupun logistik melalui brainstorming dan analisis SWOT (Strength, Weakness, Opportunity, and Threat) dan juga pengujian dengan metode AHP (Analytical Hierarchy Process) sehingga dihasilkan strategi tepat guna dan dapat diterapkan dengan baik demi kemajuan industri fashion Indonesia.

\section{REVIEW LITERATUR DAN HIPOTESIS}

Perkembangan industri pakaian jadi dipengaruhi faktor internal maupun eksternal.
Faktor internal meliputi kekuatan dan kelemahan, sedangkan faktor eksternal meliputi ancaman dan peluang yang dihadapi industri. Faktorfaktor tersebut dapat menjadi kendala dalam menghadapi ketatnya persaingan maupun menjadi kesempatan bagi industri pakaian jadi Indonesia untuk menjadi pemimpin pasar dalam negeri sendiri maupun pasar global. Namun yang perlu menjadi perhatian khusus pada industri ini adalah kondisi logistik, mengingat logistik merupakan kunci dasar dalam menentukan keberlangsungan rantai pasok setiap industri agar dapat terus memenuhi kebutuhan pasar dan upaya untuk ekspansi ke pasar yang lebih luas.

Untuk mewujudkan impian industri agar menjadi pemimpin pasar dalam negeri maupun pasar global, diperlukan strategistartegi yang tepat guna dan tepat sasaran. Strategi tersebut disusun berdasarkan faktor internal maupun faktor eksternal yang dimiliki oleh industri menggunakan metode analisis SWOT. Agar tercipta strategi yang tepat, maka dilakukan pengujian berdasarkan tingkat kepentingan terhadap faktor-faktor/pihak-pihak yang terkait dengan melakukan pengukuran terhadap alternatif-alternatif strategi yang telah disusun sebelumnya menggunakan AHP. Penilaian tingkat kepentingan tersebut dilakukan berdasarkan pendapat para pakar yang sudah ahli di bidangnya. Untuk hal ini adalah pakar di bidang fashion khususnya pakaian jadi dan di bidang logistik. Hasil dari penilaian AHP tersebut adalah strategi yang tepat guna dan tepat sasaran untuk meningkatkan kinerja industri pakaian jadi Indonesia.

\section{Logistik}

Logistik berasal dari bahasa Yunani kuno yaitu logistikos yang berarti terdidik atau pandai dalam memperkirakan atau berhitung. Yolanda (2005) mengungkapkan logistik didefinisikan sebagai bagian dari proses rantai pasok yang berfungsi merencanakan, melaksanakan, 
mengontrol secara efektif, efisien proses pengadaan, pengelolaan, penyimpanan barang, pelayanan dan informasi mulai dari titik awal hingga titik konsumsi dengan tujuan memenuhi kebutuhan konsumen. Sedangkan menurut Dwiantara dan Rumsari (2004) mendefinisikan logistik sebagai segala sesuatu atau benda yang berwujud dan dapat diperlakukan secara fisik, baik yang digunakan untuk menyelenggarakan kegiatan pokok maupun kegiatan penunjang (administrasi). Berdasarkan definisi tersebut, dapat disimpulkan bahwa logistik adalah perencanaan, pelaksanaan, pengendalian faktor produksi secara efektif dan efisien dalam rangka memperoleh barang atau jasa sejak dari titik permulaan ke titik konsumsi sesuai dengan harapan pelanggan.

\section{Analytical Hierarchy Process (AHP)}

Analytical Hierarchy Process (AHP) merupakan suatu metode yanng digunakan dalam proses pengambilan keputusan suatu masalahmasalah kompleks seperti permasalahan: perencanaan, penentuan alternatif, penyusunan prioritas, pemilihan kebijakan, alokasi sumber, penentuan kebutuhan, peramalan kebutuhan, perencanaan performance, optimasi, dan pemecahan konflik (Saaty, 1991). Suatu masalah dikatakan kompleks jika struktur permasalahan tersebut tidak jelas dan tidak tersedianya data dan informasi statistik yang akurat, sehingga input yang digunakan untuk menyelesaikan masalah ini adalah intuisi manusia. Namun intuisi ini harus datang dari orang-orang yang memahami dengan benar masalah yang ingin dipecahkan (expert). Proses pengambilan keputusan AHP dimulai dengan menerapkan tiga prinsip pemecahan masalah, yaitu penyusunan hirarki, penetapan prioritas, dan konsekuansi logis (Saaty, 1991). Penyusunan hirarki dimulai dari penetapan sasaran akhir, kriteria level pertama atau disebut faktor, sub kriteria atau aktor dan kemudian strategi alternatif.

\section{Analisis SWOT}

Menurut Jogiyanto (2005), SWOT digunakan untuk menilai kekuatan-kekuatan dan kelemahan-kelemahan dari sumber-sumber daya yang dimiliki perusahaan dan kesempatankesempatan eksternal dan tantangan-tantangan yang dihadapi. Menurut David (2008), semua organisasi memiliki kekuatan dan kelemahan dalam area fungsional bisnis. Tidak ada perusahaan yang sama kuatnya atau lemahnya dalam semua area bisnis. Kekuatan/kelemahan internal digabungkan dengan peluang/ancaman dari eksternal dan pernyataan misi yang jelas, menjadi dasar untuk penetapan tujuan dan strategi. Tujuan dan strategi ditetapkan dengan maksud memanfaatkan kekuatan internal dan mengatasi kelemahan.

\section{METODE PENELITIAN}

\section{Pengumpulan Data}

Penelitian ini bersifat kualitatif dan kuantitatifdengan menggunakan data primer. Data primer diperoleh dengan melakukan wawacara. Wawancara dilakukan kepada para enam pelaku bisnis industripakaian jadi di wilayah Jabodetabek dengan metode penyampelan snowball sampling. Hasil wawancara dipergunakan dalam melakukan analisis SWOT. Penyebaran kuesioner dilakukan kepada tiga informan yang merupakan pemain di industri pakaian jadi, yaitu pelaku bisnis di industri pakaian jadi, praktisi di bidang logistik serta staf ahli ekspor impor di kementrian perdagangan. Ketiga informan kemudian melakukan perbandingan antara dua pernyataan kemudian melakukan pilihan dari rentang skala 1 hingga 9, dan dianalisis dengan AHP. Lokasi dan waktu penelitan dilakukan di daerah Jabodetabek (Jakarta, Bogor, Depok, Tangerang dan Bekasi) pada bulan Februari hingga Maret 2016. 


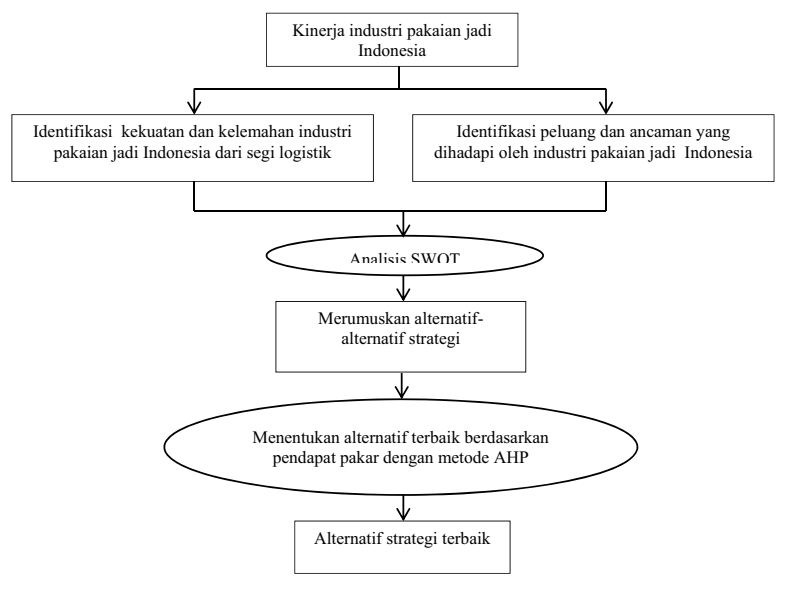

Gambar 1

\section{Kerangka Pemikiran Penelitian} Teknik Analisis Data

Analytical Hierarchy Process (AHP) merupakan suatu metode yanng digunakan dalam proses pengambilan keputusan suatu masalahmasalah kompleks seperti permasalahan: perencanaan, penentuan alternatif, penyusunan prioritas, pemilihan kebijakan, alokasi sumber, penentuan kebutuhan, peramalan kebutuhan, perencanaan performance, optimasi, dan pemecahan konflik (Saaty, 1991). Suatu masalah dikatakan kompleks jika struktur permasalahan tersebut tidak jelas dan tidak tersedianya data dan informasi statistik yang akurat, sehingga input yang digunakan untuk menyelesaikan masalah ini adalah intuisi manusia. Namun intuisi ini harus datang dari orang-orang yang memahami dengan benar masalah yang ingin dipecahkan (expert). Proses pengambilan keputusan AHP dimulai dengan menerapkan tiga prinsip pemecahan masalah, yaitu penyusunan hirarki, penetapan prioritas, dan konsekuansi logis (Saaty, 1991). Penyusunanhirarki dimulai dari penetapan sasaran akhir, kriteria level pertama atau disebut faktor, sub kriteria atau aktor dan kemudian strategi alternatif. Langkah-langkah dan prosedur dalam menyelesaikan persoalan dengan menggunakan metode AHP adalah sebagai berikut:
1. Mendefinisikan permasalahan dan menentukan tujuan

2. Membuat hirarki:

Masalah disusun dalam suatu hirarki yang diawali dengan tujuan umum, dilakukan dengan subtujuan-subtujuan, kriteria dan kemungkinan alternatif-alternatif pada tingkatan kriteria yang paling bawah

3. Melakukan perbandingan pasangan

Perbandingan dilakukan berdasarkan "judgement" dari pengambilan keputusan dengan menilai tingkat kepentingan suatu elemen dibandingkan elemen lainnya. Matriks perbandingan dapat dilihat pada tabel 1. Matriks ini menggambarkan kontribusi relatif atau pengaruh setiap elemen terhadap masing-masing tujuan atau kriteria yang setingkat diatasnya. Dimana nilai perbandingan $A_{i}$ terhadap elemen $A_{j}$ adalah $a_{i j}$. Nilai a ditentukan oleh aturan:

a. Jika $\mathrm{a}_{\mathrm{ij}}=\alpha$, maka $_{\mathrm{ij}}=1 / \alpha, \alpha \neq 0$.

b. Jika $A_{i}$ mempunyai tingkat kepentingan yang relatif sama dengan $A_{j}$, maka $a_{i j}=a_{i j}=1$.

c. Hal yang khusus, $a_{i j}=1$, untuk semua i.

Tabel 1

Matriks Perbandingan Berpasangan

\begin{tabular}{|c|c|c|c|c|c|}
\hline $\mathrm{C}$ & $\mathrm{A}_{1}$ & $\mathrm{~A}_{2}$ & $\mathrm{~A}_{3}$ & $\ldots \ldots$. & $\mathrm{A}_{\mathrm{n}}$ \\
\hline $\mathrm{A}_{1}$ & $\mathrm{a}_{11}$ & $\mathrm{a}_{12}$ & $\mathrm{a}_{13}$ & $\ldots \ldots$. & $\mathrm{a}_{1 \mathrm{n}}$ \\
\hline $\mathrm{A}_{2}$ & $\mathrm{a}_{21}$ & $\mathrm{a}_{22}$ & $\mathrm{a}_{23}$ & $\ldots \ldots$. & $\mathrm{a}_{2 \mathrm{n}}$ \\
\hline$\ldots \ldots$ & $\ldots \ldots .$. & $\ldots \ldots$. & $\ldots \ldots$. & $\ldots \ldots$. & $\ldots \ldots$. \\
\hline $\mathrm{A}_{\mathrm{n}}$ & $\mathrm{a}_{\mathrm{n} 1}$ & $\mathrm{a}_{\mathrm{n} 2}$ & $\mathrm{a}_{\mathrm{n} 3}$ & $\ldots \ldots$. & $\mathrm{a}_{\mathrm{nn}}$ \\
\hline
\end{tabular}

Sumber: Saaty (1991)

Nilai perbandingan ini ditentukan oleh skala kuantitatif yang dikemukakan oleh Saaty. Skala ini dimulai dari 1 hingga 9. Perbandingan dilakukan hingga iperoleh judgement seluruhnya sebanyak $\mathrm{n} \times[(\mathrm{n}-1) / 2]$ buah, dengan $\mathrm{n}$ adalah banyaknya elemen yang dibandingkan. 
4. Menentukan prioritas

Penyusunan prioritas dilakukan untuk tiap elemen masalah pada tingkat hirarki. Proses ini akan menghasilkan bobot atau kontribusi kriteria terhadap pencapaian tujuan. Prioritas ditentukan oleh kriteria yang mempunyai bobot paling tinggi. Bobot yang dicari dinyatakan dalam vektor $\mathrm{W}=\left(\mathrm{W}_{1}, \mathrm{~W}_{2}, \ldots\right.$, $\left.\mathrm{W}_{\mathrm{n}}\right)$. Nilai $\mathrm{W}_{\mathrm{n}}$ menyatakan bobot relatif kriteria $A_{n}$ terhadap keseluruhan set kriteria pada subsistem tersebut.

5. Menentukan tingkat konsistensi, pada keadaan sebenarnya akan terjadi ketidakkonsitenan dalam preferensi seseorang.

Pada dasarnya AHP dapat digunakan untuk mengolah data dari satu responden ahli. Namun demikian dalam aplikasinya penilaian kriteria alternatif dilakukan oleh beberapa ahli multidisipliner (kelompok). Bobot penilaian untuk penilaian berkelompok dinyatakan dengan menemukan rata-rata geometrik (Geometrik mean) dari penilaian yang diberikan oleh seluruh anggota kelompok. Nilai geometrik ini dirumuskan dengan: $\mathrm{x}_{1}$

$$
\mathrm{GM}=\sqrt[n]{(x 1)(x 2) \ldots(x n)} \sqrt[n]{(x 1)(x 2) \ldots(x n)}
$$

Dimana:

$$
\begin{array}{ll}
\mathrm{GM} & =\text { Geometric Mean } \\
\mathrm{x}_{1} & =\text { Penilaian orang ke-1 } \\
\mathrm{x}_{\mathrm{n}} & =\text { Penilaian orang ke-n } \\
\mathrm{n} & =\text { Jumlah penilai }
\end{array}
$$

\section{Analisis SWOT}

Menurut Jogiyanto (2005), SWOT digunakan untuk menilai kekuatan-kekuatan dan kelemahan-kelemahan dari sumber-sumber daya yang dimiliki perusahaan dan kesempatankesempatan eksternal dan tantangan-tantangan yang dihadapi. Menurut David (2008), semua organisasi memiliki kekuatan dan kelemahan dalam area fungsional bisnis. Tidak ada perusahaan yang sama kuatnya atau lemahnya dalam semua area bisnis. Kekuatan/kelemahan internal digabungkan dengan peluang/ancaman dari eksternal dan pernyataan misi yang jelas, menjadi dasar untuk penetapan tujuan dan strategi. Tujuan dan strategi ditetapkan dengan maksud memanfaatkan kekuatan internal dan mengatasi kelemahan. Berikut ini merupakan penjelasan dari SWOT (David, 2008), yaitu:

1. Kekuatan

Kekuatan adalah sumber daya, keterampilan, atau keunggulan-keunggulan lain yang berhubungan dengan para pesaing perusahaan yang diharapkan dapat dilayani. Kekuatan adalah kompetisi khusus yang memberikan keunggulan kompetitif bagi perusahaan di pasar.

2. Kelemahan

Kelemahan adalah keterbatasan atau kekurangan dalam sumber daya, keterampilan, dan kapabilitas yang secara efektif menghambat kinerja perusahaan. Keterbatasan tersebut dapat berupa fasilitas, sumber daya keuangan, kemampuan manajemen dan keterampilan pemasaran dapat merupakan sumber dari kelemahan perusahaan.

3. Peluang

Peluang adalah situasi penting yang menguntungkan dalam lingkungan perusahaan. Kecenderungan-kecenderungan penting merupakan salah satu sumber peluang, seperti perubahan teknologi dan meningkatnya hubungan antara perusahaan dengan pembeli atau pemasok merupakan gambaran peluang bagi perusahan.

4. Ancaman

Ancaman adalah situasi penting yang tidak menguntungkan dalam lingkungan perusahaan. Ancaman merupakan pengganggu utama bagi posisi sekarang atau yang diinginkan perusahaan. Adanya peraturan-peraturan pemerintah yang baru atau yang direvisi dapat merupakan ancaman bagi kesuksesan perusahaan. 
Analisis SWOT pun memliki fungsi seperti yang telah dikemukakan oleh Ferrel dan Harline (2005), yaitu untuk mendapatkan informasi dari analisis situasi dan memisahkannya dalam pokok persoalan internal (kekuatan dan kelemahan) dan pokok persoalan eksternal (peluang dan ancaman). Analisis SWOT tersebut akan menjelaskan apakah informasi tersebut berindikasi sesuatu yang akan membantu perusahaan mencapai tujuannya atau memberikan indikasi bahwa terdapat rintangan yang harus dihadapi atau diminimalkan untuk memenuhi pemasukan yang diinginkan. Analisis SWOT dapat digunakan dengan berbagai cara untuk meningkatkan analisis dalam usaha penetapan strategi. Umumnya yang sering digunakan adalah sebagai kerangka/panduan sistematis dalam diskusi unutk membahas kondisi alternatif dasar yang mungkin menjadi pertimbangan perusahaan.

Menurut Rangkuti (2006), matriks SWOT (tabel 2) dapat menggambarkan secara jelas bagaimana peluang dan ancaman eksternal yang dihadapi perusahaan dapat disesuaikan dengan kekuatan dan kelemahan yang dimilikinya. Matriks ini dapat menghasilkan empat set kemungkinan alternatif strategis.

\begin{tabular}{|l|l|l|}
\hline Peluang (O) & Kekuatan (S) & Kelemahan (W) \\
\hline & $\begin{array}{l}\text { Strategi SO } \\
\text { Ciptakan strategi } \\
\text { yang menggunakan } \\
\text { kekuatan untuk } \\
\text { memanfaatkan peluang }\end{array}$ & $\begin{array}{l}\text { Strategi WO } \\
\text { Ciptakan } \\
\text { strategi yang } \\
\text { meminimalkan } \\
\text { kelemahan untuk } \\
\text { memanfaatkan } \\
\text { peluang }\end{array}$ \\
\hline Ancaman (T) & $\begin{array}{l}\text { Strategi ST } \\
\text { Ciptakan stratetgi } \\
\text { yang menggunakan } \\
\text { kekuatan untuk } \\
\text { mengatasi ancaman. }\end{array}$ & $\begin{array}{l}\text { Strategi WT } \\
\text { Ciptakan } \\
\text { strategi yang } \\
\text { meminimalkan } \\
\text { kelemahan dan } \\
\text { menghindari } \\
\text { ancaman. }\end{array}$ \\
\hline
\end{tabular}

Gambar 2

Matriks SWOT
1. Strategi SO (Strength and Opportunity). Strategi ini dibuat berdasarkan jalan pikiran perusahaan, yaitu dengan memanfaatkan seluruh kekuatan untuk merebut dan memanfaatkan peluang sebesar-besarnya.

2. Stategi ST (Strength and Threat). Starategi dalam menggunakan kekuatan yang dimiliki perusahaan untuk mengatasi ancaman.

3. Strategi WO (Weakness and Opportunity). Strategi ini diterapkan berdasarkan pemanfaatan peluang yang ada dengan cara meminimalkan kelemahan yang ada.

4. Strategi WT (Weakness and Threat). Strategi ini berdasarkan kegiatan yang bersifat defensif dan berusahan meminimalkan kelemahan.

HASIL PENELITIAN DAN PEMBAHASAN

\section{Analisis SWOT}

Matriks analisis SWOT memperlihatkan delapan strategi alternatif untuk menyelesaikan hambatan logistik pada industri pakaian jadi, yaitu:

1) Mengembangkan produk pakaian jadi Industri Kecil Menengah (IKM) yang berorientasi ekspor

2) Mengembangkan variasi desain unik dan mengikuti perkembangan zaman.

3) Menambah kapasitas produksi dalam memenuhi permintaan dalam negeri

4) Menggunakan bahan baku lokal berciri khas budaya lokal sebagai bahan baku utama produksi pakaian jadi dalam negeri

5) Efisiensi produksi dengan penggunaan sumber daya (bahan baku dan biaya) untuk menghasilkan produk yang berbiaya rendah dengan kualitas yang baik serta mampu memenuhi permintaan pasar

6) Pengembangan dan penguatan pemasaran untuk produk lokal pakaian jadi

7) Pelaksanaan dan pengawasan hukum yang ketat serta tegas dalam menghadapi penyelundupan produk fashion dari luar negeri 
8) Penetapan produksi dalam negeri dengan ketentuan baku minimal $80 \%$ dari lokal

\section{Analisis AHP}

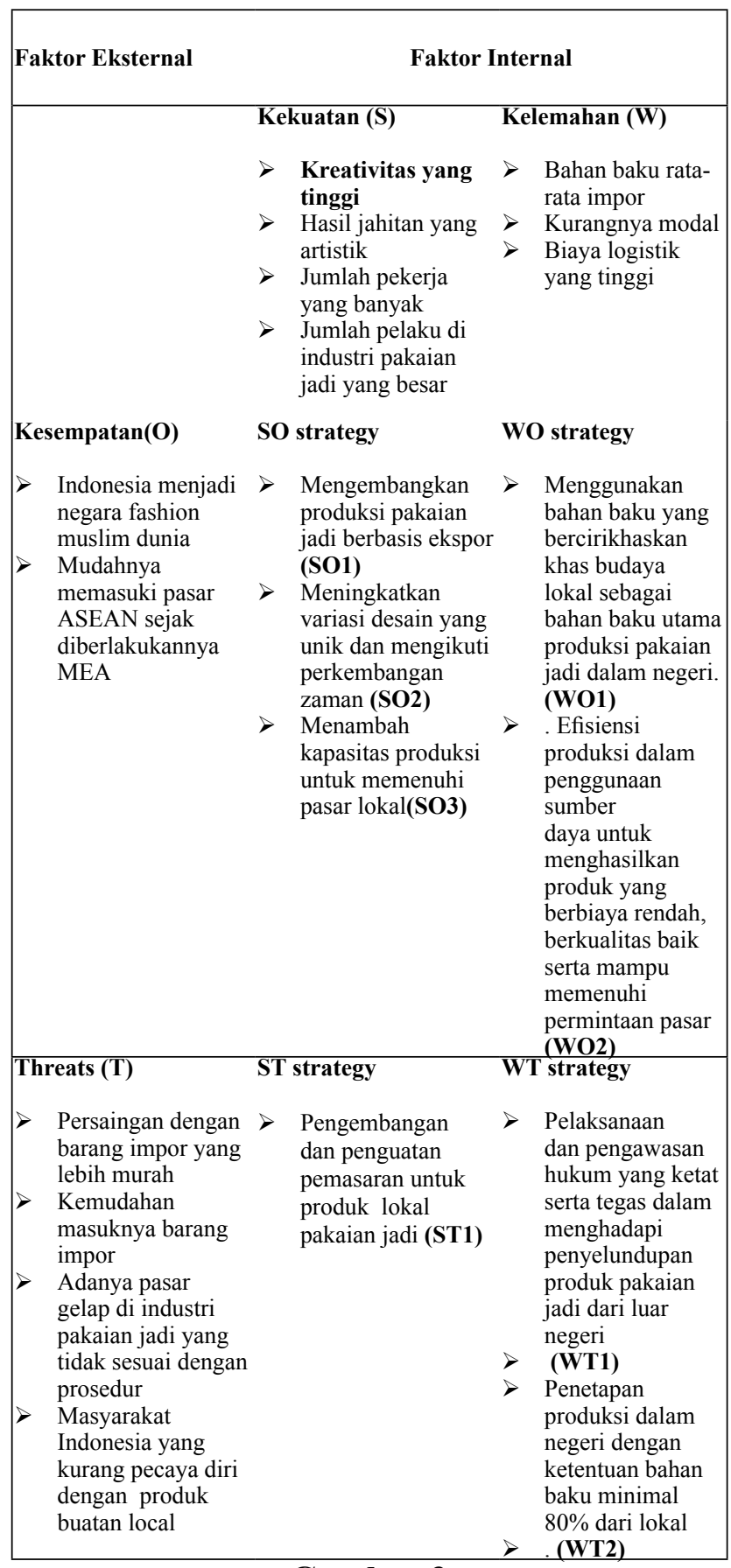

Gambar 3 Analisis SWOT
Gambar 3 memperlihatkan model AHP untuk industri pakaian jadi, AHP mengevaluasi empat hal yaitu sasaran akhir, faktor, aktor dan strategi alternatif. Tabel awal merupakan sasaran akhir yaitu pemilihan strategi logistik yang tepat untuk menngkatkan kinerja industri pakaian jadi. Tabel ke dua mengenai faktor yang menjadi peran kunci dalam meraih sasaran akhir. Tabel ke tiga mengenai aktor yang bertanggungjawab dalam meningkatkan industri pakaian jadi, dan tabel keempat memperlihatkan strategi yang digunakan untuk meningkatkan kierja industri pakaian jadi.

\section{Faktor Logistik Penentu Peningkatan Kinerja Industri Pakaian Jadi}

Hasil analisis memperlihatkan pengawasan kualitas produk adalah faktor logistik utama untuk mengatasi permasalahan dan meningkatkan kinerja industri pakaian jadi dengan nilai terbesar yaitu $(0,33)$. Faktor kedua adalah kemampuan untuk mengontrol sumber daya untuk memenuhi target produksi $(0,25)$. Faktor ketiga adalah efisiensi dan efektivitas penggunaan sumber daya $(0,153)$. Faktor keempat adalah kemampuan untuk mengetahui aliran produksi masuk dan keluar (0.122). Faktor kelima kompetensi sumber daya manusia (0.093) dan terakhir kemampuan merealisasikan ide menjadi produk nyata (0.078).

Saat ini konsumen memiliki kesadaran yang tinggi akan barang berkualitas. Namun Indonesia mengalami penurunan kualitas ekspor pada pakaian jadi dan mengalami penuruanan pangsa pasar untuk beberapa tahun terakhir (Farole dan Wrinkle, 2012). Menurut Rayadiani (2005) permasalahan utama adalah mesin dan teknologi yang digunakan sudah relatif tua. Selain itu Muslikhah et al (2016) mengungkapkan bahwa tenaga penjahit membutuhkan pelatihan dasar mengenai kualitas produk yang sesuai standar 
lokal maupun dunia. Oleh sebab itu penggunaan teknologi terkini dan juga pengembangan sumberdaya menjadi hal yang harus diperhatikan bagi berbagai pihak.

\section{Aktor Logistik dalam Peningkatan Industri Pakaian Jadi}

Tiga orang ahli digunakan dalam penelitian ini. Hasil gambar 3 menunjukkan bahwa pemilik usaha pakaian jadi merupakan aktor utama yang bertanggungjawab pada peningkatan kinerja industri pakaian jadi dengan memperoleh nilai $(0,503)$. Aktor kedua adalah staf logistik perusahaan dan yang ketiga adalah pembuat kebijakan yaitu kementrian perdagangn $(0,196)$. Kesuksesan kinerja logistik tidak dapat dipisahkan dari pemilik usaha bisnis industri pakaian jadi. Pengusaha harus mampu mengelola dari hulu ke hilir, sehingga dibutuhkan pemimpin yang visioner agara usaha tetap berkembang dan terus maju. Permasalahan yang masih sering terjadi adalah adanya kepuasan pelaku usaha dengan yang ada dan tidak melakukan inovasi pengembangan bisnis.

\section{Strategi Peningkatan Kinerja Industri Pakaian Jadi}

Sesuai dengan penjelasan sebelumnya, analisis SWOT memeberikan strategi alternatif untuk meningkatkan industri pakaian jadi, namun masih memiliki kelemahan dalam menentukan prioritas strategi yang digunakan. AHP dapat mengatasi kelemahan analisis SWOT dengan memberikan perankingan pada beberapa alternatif strategi. Gambar 3 model AHP menunjukkan bahwa pengembangan dan penguatan pemasaran produk pakaian jadi merupakan strategi menjadi perhatian utama $(0,152)$.

Produk pakaian jadi Indonesia saat ini hanya menguasai $1,1 \%$ dari seluruh dunia, dan terbesar masih didominasi RRC dengan pangsa pasar 47,2 \% (Rayadiani, 2015). Saat ini konsumen mulai menyadari fashion terutama pakaian jadi merupakan bagian terpenting dalam kehidupan karena fashion mencerminkan status, trend dan juga kepribadian. Oleh sebab itu para pemain di industri fashion khususnya pakaian jadi harus bekerjasama untuk meningkatkan pangsa pasar Indonesia di dunia. Pemilik usaha pakaian jadi harus mengkampanyekan merek lokalnya, dan peran media sangat penting untuk mempromosikan Dengan adanya kolaborasi antara suplier, desainer, dan pemilik Indonesia dapat menjadi pemain dalam rantai nilai global (www.jakartafashionweek.co.id).

Frederick (2010) mengungkapkan ada enam tingkat untuk mempertahankan rantai nilai global, yaitu 1) penelitian dan pengembangan; 2) desain; 3) produksi; 4) pembelian dan distribusi; 5) pemasaran; dan 6) jasa. Berdasarkan hasil analisis AHP dapat dijelaskan prioritas utama untuk setiap faktor, aktor dan strategi untuk meningkatkan kinerja industri pakaian jadi. Permasalahan utama adalah pengawasan kualitas produk dan strategi prioritas adalah pengembangan dan peningkatan pemasaran. Perluasan pasar dan peningkatan kualitas membutuhkan dukugan dari pemerintah, lembaga sosial, dan pengusaha. 


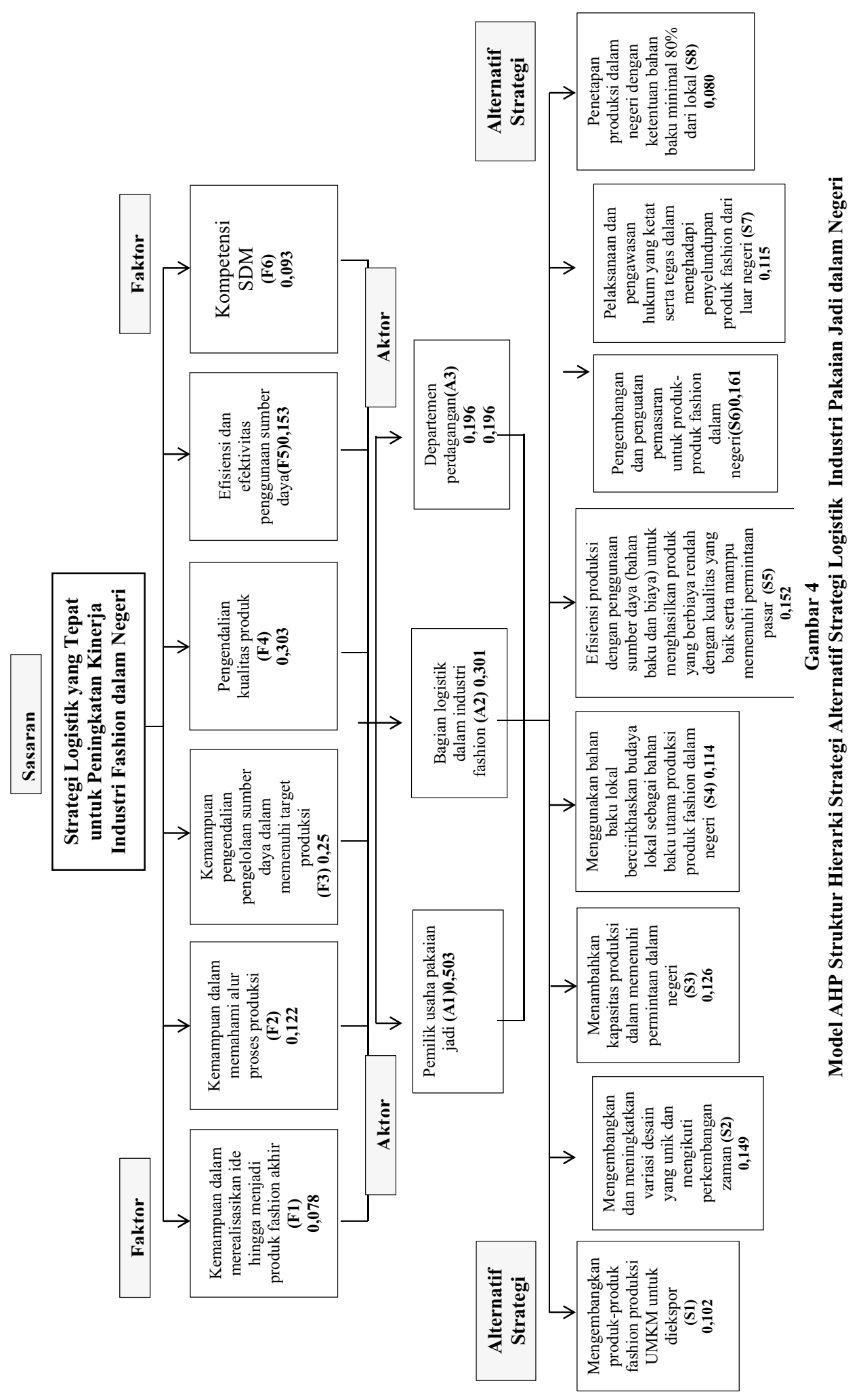




\section{KESIMPULAN DAN SARAN}

\section{Kesimpulan}

Industri pakaian jadi memiliki peranan penting dalam peningkatan ekonomi, ekspor, dan juga tenaga kerja di Indonesia. Perdagangan bebas menciptakan tantangan dan juga hambatan untuk Indonesia terutama pada industri pakaia jadi. Faktor utama yang harus diperhatikan adalah perbaikan kualitas produk. Untuk meningkatkan pangsa pasar sejalan dengan kualitas produk dilakukan dengan meningkatkan peran media sebagai media promosi, kolaborasi dari hulu ke hilir, dari suplier ke ritel dan meningkatkan promosi merek lokal.

\section{DAFTAR PUSTAKA}

David, HJ. 2009. Manajemen Strategis. Terjemahan oleh Julianto Agung. Edisi 2. Yogyakarta: Airlangga.

Dwiantara, L dan Rumsari H. 2004. Manajemen Logistik: Pedoman Praktis bagi Sekretaris dan Staff Administrasi. Jakarta: Grasindo.

Ferrel, O. C, dan D, Harline. 2005. Marketing Strategy. South Western: Thomson Corporation.

Frederick, S. 2010. Development and Application of a Value Chain Research Approach to Understand and Evaluate Internal and External Factors and Relationships Affecting Economic Competitiveness in the Textile Value Chain. Unpublished Phd Dissertation, North Carolina State University, Raleigh, NC.
Hassler, M. The Global Clothing Producton Systemains Commodity Ltd \& Chains and Business Network. Global Network 3, 4 (2003) p. 513-531. Blackwell Publishing Ltd \& Global Network Partnership.

Jogiyanto, 2005, Sistem Informasi Strategik untuk Keunggulan Kompetitif, Penerbit Andi Offset, Yogyakarta.

Muslikhah, S, Matoati, R, Sayekti, A dan Aviliani. 2016. A Analysis Tailor Worker Perfomance in Fashion Industry Case Study : Bogor and Yogyakarta. Proceeding 3rd International Conference on Management \& Muamalah.

Rayadiani, S. 2015. Produksi Pakaian Jadi Indonesia: Info Komoditi Pakaian Jadi. Badan Pengkajian dan Pengembangan Kebijakan Perdagangan. Al Mawardi Prima, Jakarta.

Rangkuti, Freddy. 2006. Analisis SWOT Teknik Membedah Kasus Bisnis. PT. Gramedia Pustaka Utama, Jakarta.

Siagian, Yolanda M. 2005. Aplikasi Supply Chain Management dalam Dunia Bisnis. Jakarta: $\quad$ PT Grasindo.

Thomas L, Saaty. 1991. Pengambilan Keputusan Bagi para Pemimpin, Proses Hirarki Analitik untuk Pengambilan keputusan dalam Situasi yang Kompleks. Jakarta: Pustaka Binama Pressindo. www.jakartafashionweek.co.id (2012). Rahasia Sukses Retail Fashion. 